\title{
On the Epistemic Value of Eros. The Relationship Between Socrates and Alcibiades
}

LAURA CANDIOTTO / University of Edinburgh /

For my friend Marian Wesoty, who knows the power of words

Several key lines concerning the relationship between Socrates and Alcibiades, extracted from the Symposium and the Alcibiades I, are discussed for the purpose of detecting the epistemic value that Plato attributed to eros in his new model of education. As result of this analysis, I will argue for the philosophical significance of the relationship between Socrates and Alcibiades as a clear example - even when failed - of the epistemic role of eros in the dialogically extended knowledge.

\section{Socrates, the teacher of Alcibiades}

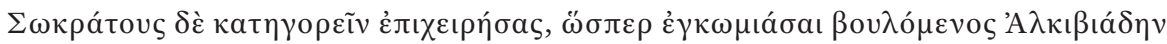

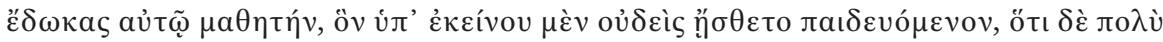

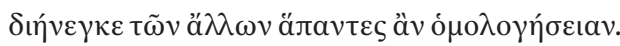


And when your purpose was to accuse Socrates, as if you wished to praise him, you gave Alcibiades to him as a pupil who, as far as anybody observed, never was taught by Socrates, but that Alcibiades far excelled all his contemporaries all would agree (Isoc. Bus. 5-6).

In this extract, Isocrates denies the relationship between Socrates and Alcibiades, saying that Alcibiades never was taught by Socrates. Isocrates defends Socrates from the attack of Polycrates who, less than a decade after Socrates' death, wrote a very critical pamphlet against him (the Kategoria Sokratous), in which he stressed the political influence of Socrates on the young. These were heated years in Athens, and the Socratic circle started to build Socrates' memory. I, thus, assume that one of the aims of the first generation of Socratics was to deny the role of Socrates as a teacher of Alcibiades, Critias, and Charmides, all of whom were adversaries to the newly established Athenian democracy after 404 BC (Allen 2010; Candiotto 2013; Danzig 2010). But the reason of doing so resides exactly in the fact that Socrates, in a very peculiar way, was really a "teacher" for this generation or, at least, for Alcibiades.

Regarding the relationship between Socrates and Alcibiades, the Socratics used different strategies to attain their apologetic aims. My aim is to discuss the Platonic approach which will not deny, as Isocrates, Thucydides and Aristophanes do, the relationship between the two, or as Xenophon does, its erotic stance. On the contrary, Plato's description, which was followed later by Plutarch, stresses both the educational and the erotic features of their relationship. ${ }^{1}$ My claim is that Plato's strategy consisted in the purification of the erotic power, attributing to it the epistemic function of motivation for inquiry, engendering of knowledge, and, therefore, ascribing to it a crucial role in education. In doing so, he established a new model of philosophical education as a reformation of the traditional paiderastia which, in his years, had almost the status of an institution. ${ }^{2}$ Specifically, the eros that binds Socrates and Alcibiades together is not the one ascribed by the pederastic relationship, but Plato confers to it new and different features. In particular, eros will be depicted as a tool of philosophical education.

As for paiderastia, this peculiar philosophical relationship between Socrates and Alcibiades pursues educative goals, but it differs from paiderastia in the following aspects:

1. the physical attraction is not sexually satisfied; ${ }^{3}$

2. Alcibiades is a 'man', or at least a 'young man', and not a 'young boy' (pais); ${ }^{4}$

1 Also Aeschines explicitly underlines the erotic relations between the two.

2 Pausanias' speech in the Symposium ( $c f$. in particular Pl. Smp.184d3-e4) summarizes its key elements. See Renaut (2016) for the connection established between eros ouranos and philosophia in Pausanias' speech.

3 'I swear to you by all the gods and goddesses together, my night with Socrates went no further than if I had spent it with my own father or older brother!', Pl. Smp. 219d (tr. A. Nehamas \& P. Woodruff in: Cooper 1997). At 222b, Alcibiades says that Socrates treated Charmides, Euthydemus, and many others in the same way.

4 'Where have you just come from, Socrates? No, don't tell me. It's pretty obvious that you've been hunting the ripe and ready Alcibiades. Well, I saw him just the other day, and he is certainly still a beautiful man - and just between the two of us, 'man' is the proper world, Socrates: his beard is already filling out' (Pl. Prt. 309a, tr. S. Lombardo \& K. Bell in: Cooper 1997). 
3. the relationship between erastes and eromenos is not fixed; 5

4. Socrates did not please Alcibiades; ${ }^{6}$

5. Socrates and Alcibiades desire that their relationship be exclusive, 7 i.e., a relationship where both partners are dating only each other; ${ }^{8}$

6. Socrates is not the well-established erastes who could facilitate the entrance of Alcibiades into the city's politics and economy. On the contrary, he dissuaded him from having an active role in Athens before being trained in philosophy. ${ }^{9}$

Plato's strategy consists precisely in reforming the traditional paiderastia ${ }^{10}$ and showing that the erotic power embedded in the relationship between teacher and student serves the epistemic function of bringing the student to philosophy. In doing so, he also establishes the practice of philosophy as the new method of education (Pl. Smp. 211b-c). ${ }^{11}$ Through philosophy, one attains wisdom, while paiderastia, at its best, is the education of the ethos in relation to the norms of the city.

\section{Philosophical education: the teacher as a mirror}

Plato's strategy did not consist in denying the relationship between Socrates and Alcibiades, rather it attributes to it a new and reformed meaning, the one of a philosophical education.

As Gary Alan Scott has underlined (Scott 2000: 13), Socrates is neither a pedagogue in the ordinary sense of the Athenian society, nor a teacher in the manner of the sophists.

5 Alcibiades is depicted as erastes too: 'he [Socrates] presents himself as your lover, and, before you know it, you're in love with him yourself!', Pl. Smp. 222b (tr. A. Nehamas \& P. Woodruff in: Cooper 1997). In the Alcibiades 1 Socrates and Alcibiades switch roles as the lover and the beloved one throughout the dialogue: '[...] we are probably going to change roles, Socrates. I'll be playing yours and you'll be playing mine, for from this day forward I will always attend on you, and you will have me as your constant companion' (Pl. Alc. 1 135d).

6 The speech of the lover in a pederastic relationship is similar to the politicians' speeches: they say what the beloved one and the public want to hear. On the contrary, Socrates continuously contradicts Alcibiades, as he is not like Callicles, who is unable to contradict his beloved one (Pl. Grg. 418d). Cf. also Pl. Alc. $1114 \mathrm{c}-\mathrm{d}$ : 'Is there any difference between an orator speaking to the people and an orator speaking in this sort of conversation, except insofar as the former persuades them all together while the latter persuades them one by one? [...] No, in fact I'm going to push you around and persuade you of the opposite of what you're not willing to show me.'

${ }^{7}$ It is interesting to note that Plutarch - maybe providing an explanation for Anytus' accusation - connects Socrates' exclusivity for Alcibiades to the denial of Anytus: 'he was harsh and stubborn with the rest of his lovers. Some of these he actually treated with the greatest insolence, as, for example, Anytus, the son of Anthemion' (Plu. Alc. 4).

8 'So, this is your situation: you, Alcibiades, son of Clinias, have no lovers and never have had any, it seems, except for one only, and he is your darling Socrates, son of Sophroniscus and Phaenarete. [...] I was your only lover - the others were only lovers of what you had' (Pl. Alc. 1 131e). Cf. also Pl. Smp. 213d and 214d.

9 'Exercise yourself first!' (Pl. Alc. 1 132b).

${ }^{10}$ For a detailed analysis of Greek paiderastia, see Lear \& Cantarella 2008. For a discussion of the Platonic account of it in the Symposium, see Brisson 2016.

${ }^{11}$ For Plato's critics of the sexual model of paiderastia in the Symposium, see Brisson 2006. 
In the Apology (Pl. Ap. 32a-33a), Plato depicts Socrates as someone who has never been anyone's teacher. At the same time, however, the Gorgias (Pl. Grg. 521d) makes clear that for Plato Socrates is the only true politician that Athens ever had, since he taught his fellow citizens through the elenchus.

The educational value of philosophy for the future statesmen, understood as a critical practice of challenging false beliefs and a care of the soul, is discussed in many dialogues. I will refer to the Alcibiades 1, since here Socrates converses with Alcibiades. Socrates says to Alcibiades that he should know himself before becoming a statesman, ${ }^{12}$ that means that he should take care of himself by doing philosophy. To do philosophy, he will need a teacher, whose role is to be like a mirror. ${ }^{13}$ Socrates is for Alcibiades the mirror that shows him in the dialogue (as elenchus) that he is not ready for politics, and, thus, he urges him to temperance (sophrosyne), as one of the most important virtues of the soul. Socrates also underlines that it is necessary to have a true lover as a mirror, not just people in general. ${ }^{14}$ In fact, the true teacher should be not only a lover - as for paiderastia - but a true lover, the one who takes care of the beloved soul, and thus who does not fear to challenge the student's false beliefs. With this line of argument, Plato builds up the epistemic value of eros at the core of the very practice of philosophy, as a dialogical inquiry for knowing thyself.

In the Alcibiades 1, Alcibiades agrees that self-cultivation is a great help ( $\mathrm{Pl}$. Alc. 1 120d) for his stupidity (Pl. Alc. 1118b) ${ }^{15}$ and he also agrees to work it out together with Socrates (Pl. Alc. 1 124d). ${ }^{16}$ But it is in the Symposium that Alcibiades' akrasia, i.e., his weakness of will, is made clear as the reason for the failure of his education. ${ }^{17}$ In the Alcibiades $1,{ }^{18}$ Alcibiades' weakness is not ascribed to his nature, ${ }^{19}$ but to the power of the city to corrupt him. In the Symposium, on the contrary, it is his pleonexia - a mental state of

12 'Get in training first, my dear friend, and learn what you need to learn before entering politics. That will give you an antidote against the terrible dangers.' (Pl. Alc. 1 132b).

${ }^{13}$ On the very famous image of knowing thyself as looking into the eyes of another as a mirror, $c f$. $\mathrm{Pl}$. Alc. $1132 \mathrm{c}-133 \mathrm{c}$.

${ }^{14}$ Socrates emphasizes to Alcibiades that he is 'falling back on teachers who are not good' (Pl. Alc. $\left.1110 \mathrm{e}\right)$.

${ }^{15}$ Alcibiades' stupidity is mentioned in the opening scene of the Protagoras too, where it is said that wisdom is much more beautiful, and that is why Socrates is more interested in Protagoras than in Alcibiades (Pl. Prt. 309c).

16 'I'm right in saying that we stand in need of self-cultivation. Actually, every human being needs self-cultivation, but especially the two of us.'

${ }_{17}$ This motive is depicted in the Gorgias too, making a contrast between the two things loved by Socrates, Alcibiades and philosophy: 'she's by far less fickle than my other beloved one. As for that son of Clinias, what he says differs from one time to the next, but what philosophy says always stays the same' (Pl. Grg. 482a).

18 The same reason is extensively explained in Pl. $R$. 494b-e where, even without an explicit reference to Alcibiades, the commentators are inclined to recognize him.

19 'I shall never forsake you now, never, unless the Athenian people make you corrupt and ugly. And that is my greatest fear, that a love of the common people might corrupt you, for many Athenian gentlemen have suffered that fate already' (Pl. Alc. 1 132a); [...] not because I distrust your nature, but because I know how powerful the city is' (Pl. Alc. 1 135e). 
insatiable desire of having more - that makes him incapable of following Socrates' advice. Or, at least, this is the reason identified by Socrates himself (Pl. Smp. 218e).

Socrates promised that he would never leave Alcibiades, as long he would be making progress (Pl. Alc. 1 131d). But the Symposium shows exactly that Alcibiades could not make any progress. Illustrating the defeat of one of the most promising young Athenians, Plato frees Socrates, and his paideia, from the responsibility for Alcibiades' bad behaviors and wrong actions.

The failure of the Socratic paideia is usually understood as an apologetic trait of Plato's writing. ${ }^{20}$ The failure should not be ascribed to the Socratic method but to the ethos of Socrates' students. This defense is made stronger by the philosophical account of epistemic love, since Plato will show that Alcibiades' fault consists in not having understood the aims of Socrates' teachings.

\section{The erotic purification}

I was the first man to fall in love with you, son of Clinias (Pl. Alc. 1 103a, tr. D. S. Hutchinson in: Cooper 1997).

With Alcibiades, Socrates plays not only the role of a lover who in the dialogue uses peitho to bring him to philosophy, but also the role of a beloved one who inflames him with the desire for wisdom. As in the Euthydemus (Pl. Euthd. 275a-b), where he wishes to 'persuade this young man here that he ought to love wisdom and have a care for virtue $^{21}$ (Pl. Euthd. 275a-b, tr. R. K. Sprague in: Cooper 1997). Eros is a powerful tool of persuasion and Plato's strategy consists in redirecting the power of eros to wisdom. In order to achieve this goal, eros should become a tool of purification (katharsis). The Socratic method is, thus, presented as one of the leading tools for achieving purification through refutation. ${ }^{22}$ Alcibiades acknowledges that Socrates made him feel ashamed of his shortcomings, providing, thereby, an excellent example of the purificatory effects produced by elenchus, which as a form of the noble sophistry (Pl. Sph. 23ob4-e5) obliges the interlocutors to be ashamed of contradictions.

${ }^{20}$ Cornelli (2016) also underlined the connection between the image of Socrates as silenus and the profanation of the herms, for which Alcibiades had been held responsible, though never explicitly. Thus, in the Symposium there is inaugurated what Cornelli (2016: 283) calls 'the Platonic politics of memory', which provides an illuminating version of the motives that lay behind the sacrilege (Alcibiades and his companions were drunk), freeing Socrates of this suspicion.

${ }^{21}$ Socrates is speaking with Clinias, the cousin of Alcibiades.

${ }^{22}$ Please see Candiotto forthcoming $a$, and 2017 for further details. 
[...] he makes it seem that my life isn't worth living! [...] He always traps me, you see, and he makes me admit that my political career is a waste of time, while all that matters is just what I neglect: my personal shortcomings, which cry out for the closest attention [...] Socrates is the only man in the world who has made me feel shame. [...]. Yes, he makes me feel ashamed: I know perfectly well that I can't prove he's wrong when he tells me what I should do; yet, the moment I leave his side, I go back to my old ways: I cave in to my desire to please the crowd. My whole life has become one constant effort to escape from him and keep away, but when I see him, I feel deeply ashamed, because I'm doing nothing about my way of life, though I have already agreed with him that I should (Pl. Smp. 216a-b).

Alcibiades highlights here that he is not only ashamed of contradictory beliefs or misconducts, but mostly of his inability to do what he knows is right. The contradiction is, thus, between theory and practice, which makes even more explicit the practical value of the Socratic method.

But purification has not only to do with the feeling of shame. The words of Socrates make Alcibiades fall in love:

If I were to describe for you what an extraordinary effect his words have always had on me (I can feel it this moment even as I'm speaking), you might actually suspect that I'm drunk! Still, I swear to you, the moment he starts to speak, I am beside myself: my heart starts leaping in my chest, the tears come streaming down my face, even the frenzied Corybantes seem sane compared to me [...] (Pl. Smp. 215e).

The deep interweaving of shame and love, that I cannot discuss in detail here, is relevant for the characterization of purification as a form of undressing. In fact, in the Alcibiades 1 ( $\mathrm{Pl}$. Alc. 1 132a-b), the purification of the soul is depicted as undressing (apodunai), understood as an inspection of the characters through the dialogue. ${ }^{23}$ The same topic appears in the Charmides ( $\mathrm{Pl}$. Chrm. $154 \mathrm{~d}-\mathrm{e}$ ), where the erotic description of the gym locker room is a metaphor for an analysis of Charmides' soul and an investigation of sophrosyne. It is interesting to note that gym was a public place where the pederastic relationship was approved and fortified. Alcibiades in the Symposium said that he and Socrates wrestled many a time in the training area without having attained anything sexual ( $\mathrm{Pl}$. Smp. 217c). Thus, we can see that Plato challenges the traditional imagery related to the pederastic education also by the literary construction of his dialogues. This is only one of the many examples of Plato's skills of modelling the scene for mediating meanings. ${ }^{24}$

Erotic relationship is still the medium through which the teacher leads the students to maturity - as paiderastia. But for Plato, this means bringing him to wisdom, choosing the Socratic style of life of purification of beliefs and caring for the soul. Conferring on

\footnotetext{
${ }^{23}$ For a deeper analysis, see Candiotto 2015.

${ }^{24}$ Literary studies on Plato's writing have been numerous in the recent years. $C f$. Rowe (2008).
} 
eros a more valuable object does not imply Socrates' asexuality or rejection of love for one individual, as many commentators have claimed..$^{25}$ Socrates' attraction for beautiful and young boys is described many times in Plato's dialogues and his erotic and seductive attitude in the dialogues cannot be denied. Sublimation for Socrates does not mean rejection of body and life - as in the famous Nietzschean interpretation (Gemes 215:260-262) but rather going through it and beyond it. Through the erotic and dialogical relationship, Socrates tries to brings his beloved Alcibiades to another level of understanding reality, the one that does not care for possessions, success, and fame, but rather for wisdom. Scott (2000: 122-123) has claimed that Socrates' denial of having a sexual intercourse with Alcibiades should be explained by his willingness to be free. On the contrary, I think that relationships are vital for the Socratic method, because only through them could Socrates bring his interlocutors to change their style of life. ${ }^{26}$ As the Diotima's speech in the Symposium points out, eros is a daimon and a metaxy, which means that it is a relational power experienced through dialogical inquiry.

Hence, Socrates rejects the 'sex for wisdom' exchange, ${ }^{27}$ while Alcibiades would expect following the traditional rules of paiderastia, because he ascribes to eros the epistemic valence of directing desires to the real good, bringing the interlocutors to face contradictions and then, eventually, engendering wisdom - as in the very well-known image of maieutic as giving birth to the truth.

\section{The dialogically extended eros}

Love as psychic energy may be channelled towards knowledge of the truth (Vallejo Campos 2011: 306), as Cornford (1950) claimed, which allows us to understand the Symposium as a gradual redirection of a single psychic energy (as recently stressed by Sassi 2011: 257). The Platonic soul is energy and mind (Dorter 1982), but also a genuine entity (Brisson 2008): as energy, it is the principle that imparts motion to matter; as mind, it uses both sensation and reason to know; as entity, it survives death. The soul as energy is erotic. According to Gordon (2012), the human soul is primordially erotic and, thanks to the recollection of the eidos of the beloved (Pl. Phd. $73 \mathrm{~d} 8$ ), it feels the desire to recollect what causes the love and, thus, achieves the recollection of Ideas/Forms.

We know from the Meno that recollection comes from dialogue ${ }^{28}$ - i.e., the maieutic process of inquiry through questions and answers. Since eros is shared by Socrates and

25 See Gill (1990) for a summary of the main interpretations.

${ }^{26}$ Socrates says to Alcibiades that he will be always available for taking decisions together, as when he says: 'In the future, let's consider things together. We'll always do what seems the best to the two of us' (Pl. Smp. 219b).

${ }_{27}$ 'You seem to me to want more than your proper share: you offer me the merest appearance of beauty, and in return you want the thing itself, "gold in exchange for bronze" (Pl. Smp. 218e-219a).

${ }^{28}$ As is well known, the recollection thesis is pursued in the Meno by the experiment of teaching geometry to a slave boy which shows that learning is recollection, since are "those who learn" ( $\mathrm{Pl}$. Men. 75e1-76a7) recollect. 
Alcibiades through dialogical interactions, and since the expected knowledge derives from these interactions, I propose to understand the foreshadowing of an ideal relationship ${ }^{29}$ between Socrates - the teacher - and Alcibiades - the student - as a case of dialogically extended knowledge (Candiotto forthcoming $a$ ), ${ }^{30}$ where eros is one of the main epistemic tools. The epistemic eros is a love of wisdom and it is dialogically extended in Socrates' and Alcibiades' relationship. While eros is understood as a common experience, only common experiences may be communicated:

Well, Callicles, if human beings didn't share common experiences, some sharing one, others sharing another, but one of us had some unique experience not shared by others, it wouldn't be easy for him to communicate what he experienced to the other. I say this because I realize that you and I are both now actually sharing a common experience: each one of the two of us is a lover of two objects; I of Alcibiades, Clinias' son, and of philosophy, and you of the demos of Athens, and the Demos who's the son of Pyrilampes (Pl. Grg. 481d, tr. D. J. Zeyl, in: Cooper 1997).

The practice of philosophy, understood as a dialogically extended inquiry, is a common experience also enhanced by erotic relationships. This very passionate philosophical experience is, thus, dialogically extended among the members of the group as, for example in the Symposium, drinking companions. They partake in a shared experience of erotic craving for knowledge. Alcibiades depicts this experience as being bitten by philosophy, and he adds that this is a common experience among companions, Socrates included. Philosophy bites in the most sensitive part - the heart, the soul or whatever you want to call it:

Well, something much more painful than a snake has bitten me in my most sensitive part I mean my heart, or my soul, or whatever you want to call it, which has been struck and bitten by philosophy, whose grip on young and eager souls is much more vicious than a viper's and makes them do the most amazing things. [...] Now, all you people here, Phaedrus, Agathon, Eryximachus, Pausanias, Aristodemus, Aristophanes - I need not mention Socrates himself and all the rest, have all shared in the madness, the Bacchic frenzy of philosophy (Pl. Smp. $218 \mathrm{a}-\mathrm{b})$.

Also Socrates felt this state of erotic mania (Pl. Phdr. 244a). Using eroticism in teaching philosophy, Socrates turned the intimacy of the erotic moment of a couple into a distributed excitation for the love of wisdom. In this way, the philosophical relation

\footnotetext{
29 As I will explain in the next section, this ideal relationship has not been realized.

${ }^{30}$ By "dialogically extended knowledge" I mean that interlocutors are parts of an extended cognitive system created by dialogical interactions.
} 
should not be exclusive (as required by the point 5 described above in the section 1), but it should consist in the dialogically extended eroticism for wisdom.

\section{Alcibiades' failure}

Arguably, the dialogically extended eros did not produced the expected results in Alcibiades. ${ }^{31}$ The reason of this failure resides in the fact that Socrates and Alcibiades understood the nature of the love they shared very differently. And this is the tragedy of their relationship (Nussbaum 1994). Eros for Socrates is epistemic, but for Alcibiades it is only sexual, and categorized within the traditional pederastic model, "[...] all I had to do was to let him have his way with me, and he would teach me everything he knew” (Pl. Smp. 217a).

Moreover, Alcibiades does not understand the mutuality proposed by Socrates, but he feels to be Socrates' slave (Pl. Smp. 219e), using, again, the pederastic paradigm of domination and submission. It is important to remember that this cognitive failure was created by Plato to defend Socrates from the attack of Polycrates and others, thus, constituting his apologetic memory. The failure should be, thus, contextualized to Socrates and Alcibiades' relationship and not extended to the very meaning of eros as epistemic tool..$^{22}$ Plato created a new educative model understood as a metamorphosis of the traditional paiderastia for his own philosophical goals, but also for Socrates' apology, arguing that the love which Socrates felt for Alcibiades was epistemic and very different from the one felt by Alcibiades. Plato had to ascribe to Alcibiades the faults of his pedagogical failure and, thus, his incapacity of understanding the epistemic valence of eros is one of the reasons of his downfall.

\section{Conclusion}

Dialogically extended knowledge, in both the refutatory and the maieutic ${ }^{33}$ phase, is an alternative to paiderastia (Hobbs 2006) and it serves as one of the best method for doing philosophy together. Doing philosophy together means also knowing our souls (Pl. Alc. 1 130e). The tragedy of Socrates' and Alcibiades' relationship, but, at the same time, the apology of Socrates, is that his pupil, Alcibiades, was not able to see in Socrates the philosopher, as he did not understand that the teacher is his mirror and that the love which is extended in the relationship is epistemic. To do so, he should have been able to

\footnotetext{
${ }^{31}$ On the failure of a real communion of the souls between Socrates and Alcibiades, see Hatzfeld 1951: 52.

32 To properly evaluate this point, it is necessary to analyze other dialogues too, and not only having the relationship between Socrates and Alcibiades as focus.

${ }^{33}$ A powerful image of it in Alcibiades 1 appears in 135 where it is said: 'Then my love for you, my excellent friend, will be just like a stork: after hatching a winged love in you, it will be cared for by it in return.'
} 
understand that "the mind's sight becomes sharp only when the body's eyes go past their prime" (Pl. Alc. 1 219a). But this is asking too much from Alcibiades, who was imbued with misapprehended love.

\section{Acknowledgement}

This paper arises from the project "Emotions First" (Marie Curie Individual Fellowship, Horizon 2020. Grant: 655143 - EMOTIONS FIRST) funded by the EU Commission. 


\section{BIBLIOGRAPHY}

Allen, D., 2010, Why Plato Wrote, Malden.

Brisson, L., 2016, “Éros éducateur: entre paiderastía et philósophia”, in: M. Tulli. M. Erler (eds.), Plato in Symposium. Selected Papers from the Tenth Symposium Platonicum, Sankt Augustin, pp. 24-35.

Brisson, L., 2006, “Agathon, Pausanias, and Diotima in Plato's Symposium. Paiderastia and Philosophia”, in: J. H. Lesher, D. Nails, F. C. C. Sheffield (eds.), Plato's Symposium. Issues in Interpretation and Reception, Cambridge, pp. 229-251.

Brisson, L., 2008. “Reminiscence in Plato”, in: J. Dillon, M.-É. Zovko (eds.), Platonism and Forms of Intelligence, Sankt Augustin, pp. 179-190.

Candiotto, L., fortchoming $a$. "Plato's dialogically extended cognition. Cognitive transformation as elenctic catharsis", in: P. Meinek, J. Devereux (eds.), Routledge Companion to Classics and Cognitive Theory, Routledge.

Candiotto, L., 2017. “Purification through emotions. The role of shame in Plato's Sophist 230b4-e5”, Educational Philosophy and Theory (special issue "Bildung and paideia: Philosophical Models of Education", eds. J. Dillon, M. L. Zovko). http://dx.doi.org/10.1080/00131857.2017.1373338

Candiotro, L., 2015, "Aporetic State and Extended Emotions: the Shameful Recognition of Contradictions in the Socratic Elenchus”, Ethics \& Politics 17, pp. 233-248 (special issue on “The Legacy of Bernard Williams's Shame and Necessity”, ed. A. Fussi).

Candiotto, L., 2013, “Socrate e l'educazione dei giovani aristocratici”, in: A. Stavru, F. De Luise (eds.). Socratica III, Sankt Augustine, pp. 190-198.

Cooper, J. M. (ed.), 1997, Plato, Complete Works, Indianapolis-Cambridge.

Cornelli, G., 2016, "He longs for him, he hates him and he wants him for himself: The Alcibiades Case between Socrates and Plato", in: G. Cornelli (ed.), Plato's Style and Character, Berlin-Boston, pp. 281-295.

CoRnford, F. M., 1950 (first version 1937). “The Doctrine of Eros in Plato's Symposium”, in: F. M. Cornford, The Unwritten Philosophy and Other Essays, pp. Cambridge, pp. 68-80.

DANzig, G., 2010, Apologizing for Socrates. How Plato and Xenophon Created Our Socrates, Lanham.

DorTER, K., 1982, Plato's Phaedo: An Interpretation, Toronto-London.

GEMEs, K., 2015, "Freud and Nietzsche on the Nature and Value of Sublimation", Iyyun - The Jerusalem Philosophical Quarterly 64, pp. 243-263.

GILL, C., 1990, "Platonic Love and Individuality”, in: A. Loizon, H. Lesser (eds.), Polis and Politics. Essays in Greek Moral and Political Philosophy, Aldeshot, pp. 69-88.

Gordon, J., 2012, Plato's Erotic World. From Cosmic Origins to Human Death, Cambridge.

Hatzefeld, J., 1951, Alcibiade. Étude sur l'histoire d'Athènes à la fin du V siècle, Paris.

Новвs, A., 2006, “Female Imagery in Plato”, in: J. H. Lesher, D. Nails, F. C. C. Sheffield (eds.), Plato’s Symposium. Issues in Interpretation and Reception, Cambridge, pp. 252-271.

Lear, A., CANTARella, E., 2008, Images of ancient Greek pederasty: boys were their Gods, London-New York.

Nussbaum, M., 1994, "Platonic Love and Colorado Law: the Relevance of Ancient Greek Norms to Modern Sexual Controversies”, Virginia Law Review 80, pp. 1515-1651.

Renaut, O., 2016, “La pédérastie selon Pausanias: un défi pour l'éducation platonicienne”, in: M. Tulli, M. Erler (eds.), Plato in Symposium. Selected Papers from the Tenth Symposium Platonicum, Sankt Augustin, pp. 140-147.

Rowe, C., 2008, Plato and the Art of Philosophical Writing, Cambridge. 
Rudebusch, G., 2009, “Socratic Love”, in: S. Ahbel-Rappe, R. Kamtekar (eds.), A Companion to Socrates, Chichester, pp. 186-199.

SAssi, M. M., 2011, "Eros as psychic energy. Plato and fluxes of the soul”, in: M. Migliori, L. Napolitano Valditara, A. Fermani (eds.), Inner Life and Soul. Psychê in Plato, Sankt Augustin, pp. 251-265.

ScotT, G. A., 2000, Plato's Socrates as Educator, Albany.

Vallejo Campos, A., 2011, “The images of the Good and the interior life of the soul”, in: M. Migliori, L. Napolitano Valditara, A. Fermani (eds.), Inner Life and Soul. Psychê in Plato, Sankt Augustin, pp. 299-306.

LAURA CANDIOTTO

/ University of Edinburgh, UK/

Laura.Candiotto@ed.ac.uk

KEY WOR DS

\section{On the Epistemic Value of Eros. The Relationship Between Socrates and Alcibiades}

Several key lines concerning the relationship between Socrates and Alcibiades, extracted from the Symposium and the Alcibiades 1, are discussed for the purpose of detecting the epistemic value that Plato attributed to eros in his new model of education. As result of this analysis, I argue for the philosophical significance of the relationship between Socrates and Alcibiades as a clear example - even when failed - of the epistemic role of eros in the dialogically extended knowledge.

Eros, education, Socrates, Alcibiades, Plato 